\title{
Reforestation and slope-position effects on nitrogen, phosphorus pools, and carbon stability of various soil aggregates in a red soil hilly land of subtropical China
}

\author{
Li-Qun Zou, Fu-Sheng Chen, David S. Duncan, Xiang-Min Fang, and Huimin Wang
}

\begin{abstract}
The impact of slope position on forest restoration processes may dominate the interaction among topsoil aggregates, nutrients, and organic carbon (C) stability following reforestation on degraded hilly land. Six paired plots of shrubland and Masson pine (Pinus massoniana Lamb.) plantation reforested on shrubland were selected at different positions along a $25^{\circ}$ slope in subtropical China. Soil and ecosystem nitrogen $(\mathrm{N})$, phosphorus $(\mathrm{P})$, and organic $\mathrm{C}$ stocks were quantified using a combination of excavation, harvest, and modeling methods. Carbon stability in differently sized soil aggregates was measured using dry sieving and closed-jar alkali-absorption methods. Reforestation increased total ecosystem C, N, and P stocks, but did not alter soil C and P stocks, and decreased $\mathrm{N}$ stocks at 0-75 $\mathrm{cm}$ soil depth by $18 \%$. The shift from shrubland to forests increased organic C stability for various soil aggregates, particularly with a mean increase of $34 \%$ and $30 \%$ at lower and middle slope positions, respectively. The slope-position effect was largely attributable to the increased mean mass diameter of soil aggregates and the reduced organic $\mathrm{C}$ mineralization potential in larger soil aggregates relative to smaller soil aggregates. Soil aggregates had more stable organic $C$ in forests than in shrubland due to increase in the carbon to nitrogen $(C / N)$ and carbon to phosphorus $(C / P)$ ratios with reforestation. Slope position influenced restoration effectiveness in the red soil hilly region.
\end{abstract}

Key words: biogeochemistry, ecosystem function, land-use change, organic carbon mineralization, soil property.

Résumé : L'impact de la position dans la pente sur les processus associés à la restauration de la forêt pourrait dominer l'interaction parmi les agrégats des horizons superficiels, les nutriments et la stabilité du C organique à la suite du reboisement en terrain accidenté et dégradé. Six placettes appariées contenant des arbustes ou une plantation de pin rouge chinois (Pinus massoniana Lamb.) reboisé dans une zone arbustive ont été établies à différents endroits le long d'une pente de $25^{\circ}$ dans la partie subtropicale de la Chine. Les stocks de N, $\mathrm{P}$ et C organique ont été quantifiés dans le sol et l'écosystème en combinant excavation, récolte et modélisation. La stabilité de $C$ dans les agrégats de sol de différentes tailles a été mesurée en utilisant le tamisage à sec et l'absorption de bases en contenant fermé. Le reboisement a augmenté les stocks totaux de $\mathrm{C}, \mathrm{N}$ et $\mathrm{P}$ dans l'écosystème mais n'a pas modifié les stocks de $\mathrm{C}$ et $\mathrm{P}$ dans le sol et a diminué les stocks de $\mathrm{N}$ de $18 \%$ à une profondeur de 0-75 $\mathrm{cm}$ dans le sol. Le fait de passer d'une formation arbustive à la forêt a augmenté la stabilité du C organique pour une variété d'agrégats de sol, particulièrement avec une moyenne de $34 \%$ et $30 \%$ respectivement au bas et au milieu de la pente. L'effet de la position sur la pente était en grande partie attribuable à l'augmentation du diamètre moyen des agrégats de sol et à la réduction de la capacité de minéralisation du $\mathrm{C}$ organique dans les gros agrégats de sol comparativement aux agrégats plus petits. Les agrégats de sol contenaient plus de $\mathrm{C}$ stable dans la forêt que dans la formation arbustive parce que le reboisement a augmenté les rapports $\mathrm{C} / \mathrm{N}$ et C/P. La position sur la pente a influencé l'efficacité du reboisement sur les sols rouges en terrain accidenté. [Traduit par la Rédaction]

Mots-clés : biogéochimie, fonction de l'écosystème, changement d'affectation des terres, minéralisation du carbone organique, propriétés du sol.

\section{Introduction}

Reforestation and afforestation are popular means of improving ecological functionality while combating poverty in degraded hilly and mountainous ecosystems (Li 2004). In 2005, approximately 140 million ha were under reforestation plantations globally, with a potential increase of 34 million ha by 2020 (Berthrong et al. 2009). In China, forest plantation area increased to 69.33 million ha in 2014, becoming the largest around the world according to the data of the eighth national forest resources inventory (www.xinhuanet.com/zhibo/20140225a/zhibo.htm). Although these numbers are impressive, the quality of forest establishment, rather than just the acreage, is critical to meet growing environmental, social, and economic demands on a finite land base (Tang et al. 2010).

Nutrient management and carbon sequestration frequently provide motivation for forest establishment efforts on barren hills (Gong et al. 2013; Liu et al. 2012). Soil nutrients and organic carbon (C) are rapidly lost following deforestation and cultivation (Brown and Lugo 1990; Lal 2005), and it has been suggested that afforestation or reforestation may offset or reverse this process (Hooker

Received 9 June 2014. Accepted 14 September 2014.

L.-Q. Zou, F.-S. Chen, and X.-M. Fang. Jiulianshan National Observation and Research Station of Chinese Forest Ecosystem, College of Forestry, Jiangxi Agricultural University, No. 1101, Zhiminda Road, Nanchang Economic and Technology Development Zone, Nanchang 330045, China.

D.S. Duncan. Department of Agronomy, University of Wisconsin, Madison, WI 53706, USA.

H. Wang. Qianyanzhou Ecological Station, Key Laboratory of Ecosystem Network Observation and Modeling, Institute of Geographic Sciences and Natural Resources Research, Chinese Academy of Sciences, Beijing 100101, China.

Corresponding author: Fu-Sheng Chen (e-mail: chenfush@yahoo.com). 
and Compton 2003). Maturing forests serve as a sink of atmospheric $\mathrm{CO}_{2}$ (Huang et al. 2012), making forest establishment a popular mechanism for global C offsets (Fang et al. 2001). Carbon cycling is closely coupled to nitrogen $(\mathrm{N})$ and phosphorus $(\mathrm{P}) \mathrm{dy}-$ namics in forest ecosystems (Yang et al. 2014). Despite the importance of these ecological functions, it remains unclear how they can be best improved by management of forest establishment on barren hills (Li et al. 2012; Wei et al. 2013). In particular, there is a limited understanding of the role that topography plays in the ecological behavior of established forests (Tang et al. 2010).

The influence of topography on soil nutrients and plant growth has been well recognized at the watershed scale and at larger scales (Fu et al. 2004; Luizâo et al. 2004), but the role of position within a hill slope has sometimes been ignored, especially for subtropical forests (Tang et al. 2010). The nature of these effects may depend upon the soil type and climate conditions (Wei et al. 2010). Soil organic $C$ accumulation is strongly affected by erosion and deposition dynamics that are sensitive to slope position (Tang et al. 2010; Wei et al. 2010). Soil aggregation and aggregate turnover are key dynamics in soil biogeochemical cycling (Six et al. 2000), and the sensitivity of aggregates to slope position has been shown to impact organic C sequestration (Tang et al. 2010).

The Jiangxi Province in China provides a particularly good context for evaluating the benefits of forest establishment on barren hills. Much of the area is covered by Ultisols, locally referred to as "red clay", which are highly susceptible to erosion and suffer from low nutrient availability and high stone content (Gong et al. 2013; Wei et al. 2013). To control soil erosion and restore ecosystem functionality, the Jiangxi government instituted an aggressive reforestation program in the mid 1980s, and by 2014 , they had succeeded in increasing the forest cover from $32 \%$ to $64 \%$ of the total land area. To evaluate the benefits of reforestation, we compared the effect of slope position on the $\mathrm{C}, \mathrm{N}$, and $\mathrm{P}$ cycling properties of the recently established forests with the properties of their neighboring secondary shrubland, which is the initial state before reforestation. Our main aims were as follows: (i) to quantify the relative magnitude of $\mathrm{C}, \mathrm{N}$, and $\mathrm{P}$ stocks in soil and ecosystem levels and analyze their interactions under forests and shrubland; and (ii) to compare the size distribution, organic C stability, and nutrient contents of soil aggregates at different slope positions under forest and shrubland cover. We hypothesize that reforestation increased soil organic $C$ stability through the improvement of soil aggregate composition and nutrient content in a hilly, highly degraded area.

\section{Materials and methods}

\section{Study area and selected plots}

The study area was located at a typical red soil hilly land in Taihe County, Jiangxi Province of southern China (latitude $26^{\circ} 44^{\prime} \mathrm{N}$, longitude $\left.115^{\circ} 04^{\prime} \mathrm{E}\right)$. It has a subtropical, moist monsoon climate, with a warm, dry summer and a cool, wet winter. The mean annual precipitation is $1500 \mathrm{~mm}$. Maximum and minimum mean monthly temperatures are $29.7^{\circ} \mathrm{C}$ in July and $6.5^{\circ} \mathrm{C}$ in January, and the mean annual temperature is $17.9^{\circ} \mathrm{C}$. Local soils are Ultisols (i.e., red soil) (Zhao 2002). The elevation is from 30 to $200 \mathrm{~m}$ above sea level.

The research site was located within a 640 ha study area established in 1990 to evaluate various species compositions for reforestation (Liu et al. 2012). Prior to reforestation, the area had a history of frequent human disturbance, particularly firewood collection. This deforestation led to dominance by secondary shrubland, which are characteristic of a disturbance plagioclimax community commonly found in deforested lands in subtropical China (Liu and Guo 1997). Reforestation was begun in April 1991 by planting nursery-raised seedlings with a $1.5 \mathrm{~m} \times 2 \mathrm{~m}$ spacing. Once the seedlings were planted, no further management was conducted in the area.

Our study looked at a strip of shrubland where trees were not planted during the reforestation process. The strip was located in the middle of a $250 \mathrm{~m}$ wide slope on a $25^{\circ}$ gradient and measured $60 \mathrm{~m}$ wide $\times 110 \mathrm{~m}$ long. We separated this strip into three areas of approximately equal size, corresponding to the top, middle, and bottom slope positions. For each slope position, we established $10 \mathrm{~m} \times 10 \mathrm{~m}$ plots near both forest-adjacent edges in the shrubland strip, with paired equal-sized plots located within the forested area (see Supplementary Fig. $S 1^{1}$ for the schematic).

Dominant shrub and herb species in the strip included Arundinella anomala Steud., Cymbopogon goeringii (Steud.) A. Camus, Heteropogon contortus (L.) P. Beauv. ex Roem. \& Schult., and Setaria viridis (L.) P. Beauv.; the community composition resembled what was described immediately prior to reforestation (Liu and Guo 1997). The forested area surrounding the shrubland strip was planted with Masson pine (Pinus massoniana Lamb.). Major understory plants in the reforested area included Arundinella anomala, Cymbopogon citratus (DC.) Stapf, Eurya japonica Thunb., Melastoma dodecandrum Lour., Phyllanthus urinaria L., Rhamnus crenata Siebold \& Zucc., Rosa laevigata Michx., Smilax china L., and Viola philippica Cav.

\section{Investigation and sampling}

\section{Belowground ecosystem}

In July of 2010 , we selected three random $50 \mathrm{~cm} \times 50 \mathrm{~cm}$ locations from each $10 \mathrm{~m} \times 10 \mathrm{~m}$ plot. At each location, we excavated $15 \mathrm{~cm}$ deep layers of soil to a total depth of $75 \mathrm{~cm}$, resulting in sample at the following five depths: 0-15, 15-30, 30-45, 45-60, and $60-75 \mathrm{~cm}$. Below $75 \mathrm{~cm}$, the soil became too rocky to sample. The intact layers were placed in specimen boxes and used for aggregate grading, bulk density measurement, stone $(>2 \mathrm{~mm}$ diameter soil particles) mass measurement, and nutrient quantification. The remainder of the soil in each layer was used to measure root biomass and soil properties. Both sample types were composited in the lab to produce a single measurement for each plot. Our sampling locations were sufficiently far from the forest-shrubland boundary that we were not concerned about contaminating roots from the adjacent treatment.

\section{Aboveground ecosystem}

Due to fundamental differences in the dominant vegetation, aboveground measurements were conducted differently in shrubland and forest plots. In shrubland plots, we harvested all secondary shrubland vegetation, whether living or dead, from three randomly placed $1 \mathrm{~m} \times 1 \mathrm{~m}$ subplots and obtained weights following air drying. For all trees in the forest plots, we measured height and diameter at breast height ( $\mathrm{dbh} ; 1.3 \mathrm{~m})$. We selected five representative trees per plot from which to sample main stems (three growth cores), lateral branches, and leaves for nutrient concentration measurements. Leaves and branches were collected from four directions of the middle crown. The biomasses of main stems, lateral branches, and leaves were estimated based on allometric regression models previously developed by Chen et al. (2012) (see Supplementary Table $S 1^{1}$ ). In addition, three randomly placed $1 \mathrm{~m} \times 1 \mathrm{~m}$ subplots were used to collect and measure understory vegetation biomass. We summed tree and understory vegetation biomasses on an area basis to calculate plant biomass in the reforested area. All plant materials were dried at $65{ }^{\circ} \mathrm{C}$ and then ground for the analyses of organic $\mathrm{C}$ and nutrients.

${ }^{1}$ Supplementary data are available with the article through the journal Web site at http://nrcresearchpress.com/doi/suppl/10.1139/cjfr-2014-0275. 
Fig. 1. Soil ( $a$ ) bulk density and (b) stone mass percentage by land-use type, slope position, and soil depth in a hilly red soil land of subtropical China. Error bars represent \pm 1 standard error. Significance levels: NS, not significant; ${ }^{*}, p<0.05 ;{ }^{* *}, p<0.01$; ${ }^{* *}, p<0.001$. Different lowercase letters indicate significantly different values at 0-75 cm depth among land use type slope positions at the $p<0.05$ level.

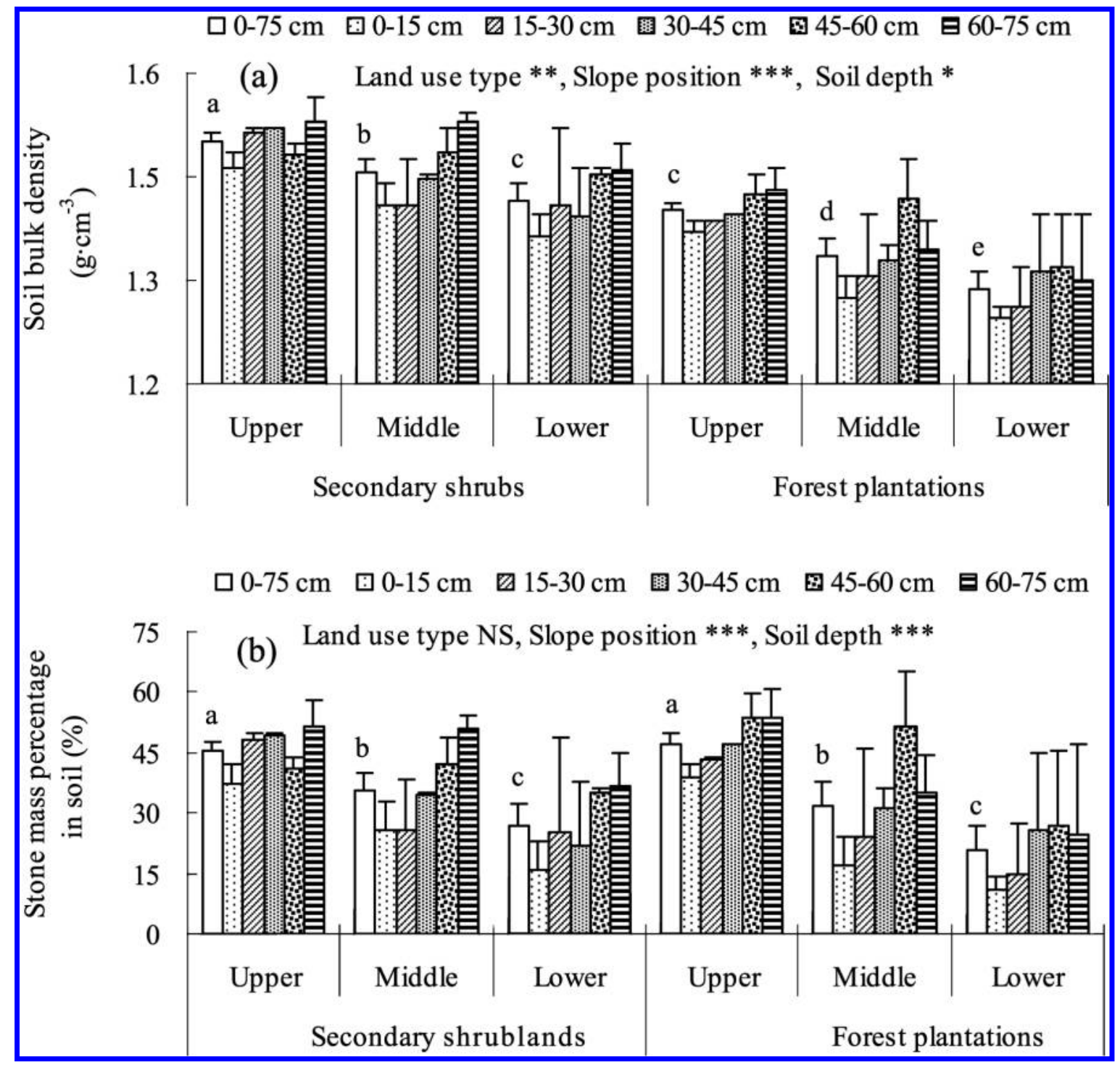

\section{Analytical methods}

\section{Soil-aggregate fractionation}

Following the procedures provided by Kemper and Rosenau (1986), intact soil blocks were crumbled by hand into pieces approximately $10 \mathrm{~mm}$ in diameter. After being air-dried for a week, soil subsamples were placed in airtight plastic boxes at $4{ }^{\circ} \mathrm{C}$ to maintain a suitable moisture level for sieving (Sainju 2006). Triplicate $500 \mathrm{~g}$ subsamples from each sample were passed through nested sieves with $5,2,1,0.5$, and $0.25 \mathrm{~mm}$ mesh. Sieves were placed on a RO-TAP sieve shaker (Xinxiang City Vibration Sift Machinery Factory Co., LTD, Henan, China) and shaken at 200 oscillations $\cdot \mathrm{min}^{-1}$ for $5 \mathrm{~min}$. Aggregates retained at each sieving level were fully air-dried and then weighed after the removal of small stones $(>2 \mathrm{~mm})$ and plant residues. Mean mass diameter (MMD) of aggregates was calculated by multiplying the mean diameter of each aggregate size class by its proportion of total soil mass and summing over all size classes (Kemper and Rosenau 1986).

\section{Soil organic $C$ mineralization potential}

Soil organic $\mathrm{C}$ mineralization potential was estimated by measuring $\mathrm{CO}_{2}$ evolution from incubated bulk soils and samples from each aggregate size class drawn from the top $15 \mathrm{~cm}$ of soil. Duplicate $20 \mathrm{~g}$ soil samples with the particulate organic matter removed were moistened with distilled water to $50 \%$ field capacity and placed in a $500 \mathrm{~mL}$ chamber. To ensure an active microbial community, incubation chambers were inoculated with a suspension of fresh topsoil from their respective source plots and allowed to rest for $24 \mathrm{~h}$ before being sealed and incubated at $25^{\circ} \mathrm{C}$. Sealed chambers contained alkaline $\mathrm{CO}_{2}$ traps that consisted of $5 \mathrm{~mL}$ of $2 \mathrm{~mol} \cdot \mathrm{L}^{-1} \mathrm{NaOH}$ in $10 \mathrm{~mL}$ beakers. The $\mathrm{CO}_{2}$ traps were changed on days $5,10,17,24,34,44,54,64$, and 74 of the incubation, and total $\mathrm{CO}_{2}$ emission was measured by precipitation of $\mathrm{CO}_{2}$ with $\mathrm{BaCl}_{2}$ and titration with $\mathrm{HCl}$. Soils were remoistened each time the $\mathrm{CO}_{2}$ trap was changed.

\section{Nutrient measurement in soil and plant}

All soil and plant materials were oven-dried, ground, and sieved with a $0.2 \mathrm{~mm}$ screen prior to nutrient measurement. Soil organic C concentration was determined by the potassium dichromate oxidation - ferrous sulphate titrimetry method. Total $\mathrm{N}$ and $\mathrm{P}$ was determined by the Kjeldahl method and colorimetric method, respectively, after $\mathrm{H}_{2} \mathrm{SO}_{4}$ digestion (Allen 1989). 
Fig. 2. Relative distribution of soil aggregate size classes by land-use type, slope position, and soil depth in a hilly red soil land of subtropical China. Error bars represent \pm 1 standard error. Different lowercase letters indicate significantly different percentage aggregate values at soil depths of $0-15,15-30$, and $30-45 \mathrm{~cm}$ among land use type slope positions at the $p<0.05$ level. Note the differences in scale.

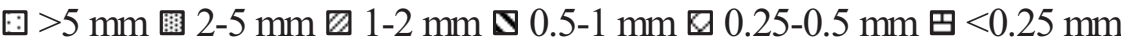
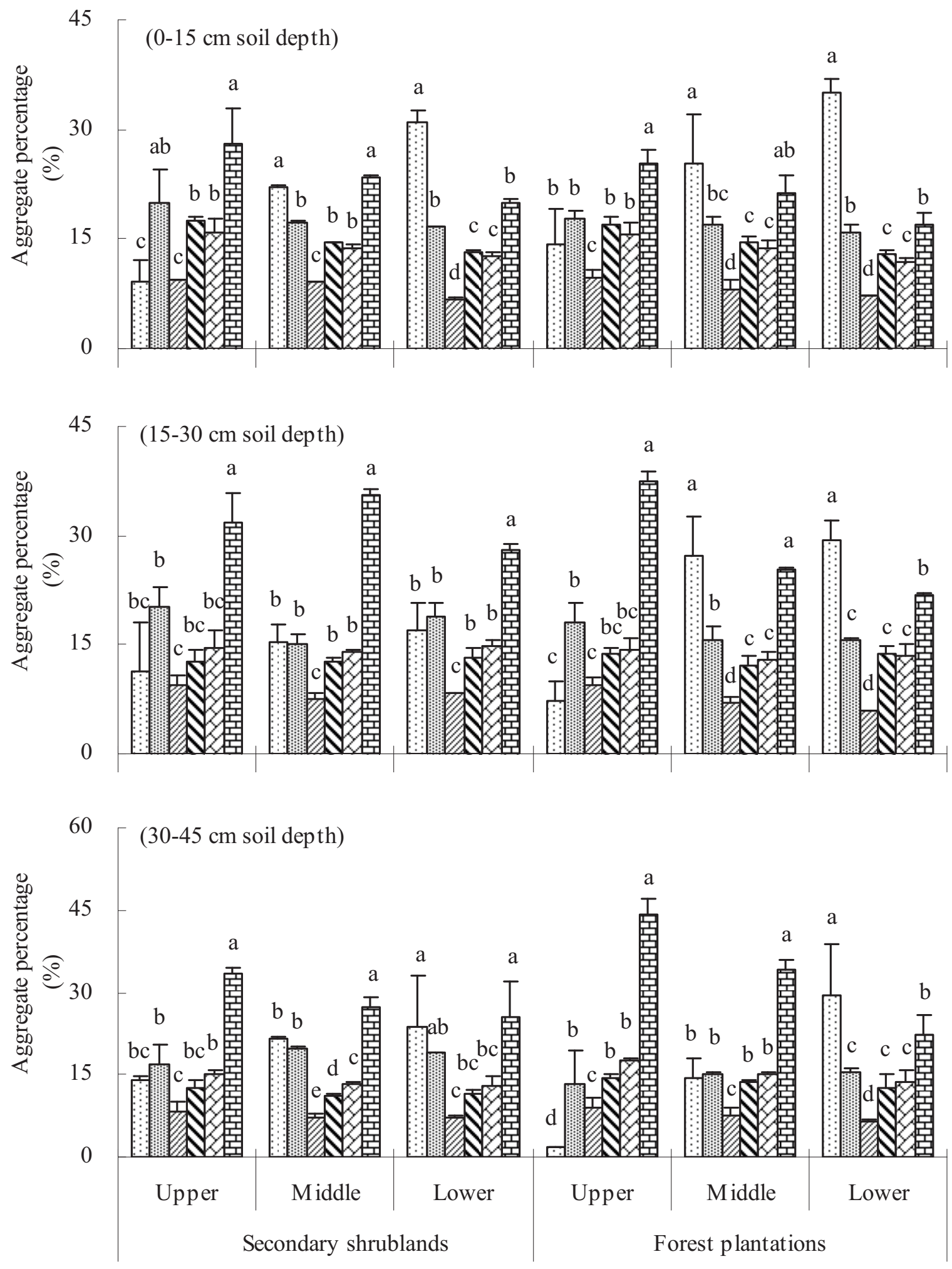


\section{Data processing}

All statistical analyses were conducted using SPSS version 16.0 (SPSS 2007). Multiple-way analysis of variance (ANOVA) was used to evaluate land-use type, slope position, soil depth, and aggregate size. Paired-sample $t$ test was used to compare differences between secondary shrubland and forest plantations. One-way ANOVA and least significant difference (LSD) methods were used to compare the differences. The standard $\alpha=0.05$ level was used throughout as a cutoff for statistical significance.

\section{Results}

\section{Soil physical properties}

Bulk density was lower in forests than in shrubland both near the soil surface $(0-15 \mathrm{~cm})$ and for the entire measured profile $(0-75 \mathrm{~cm})$ (Fig. 1a). For both land-use types, the bulk density increased with higher slope position (Fig. 1a). The percentage of soil mass composed of stones increased significantly with higher slope position, but was not different between the two land uses (Fig. 1b).

The proportional mass of different soil aggregates generally differed by slope position but not by land-use type, except for the 2-5 mm size (Fig. 2). The strongest effects of slope were observed in the largest $(>5 \mathrm{~mm})$ and smallest $(<0.25 \mathrm{~mm})$ aggregates. The largest aggregates tended to make up a greater proportion of soil mass at lower slope positions, whereas smaller aggregates were generally more prevalent at higher slope positions (Fig. 2). Aggregate MMD increased from $1.69 \mathrm{~mm}$ in upper slope positions to $2.45 \mathrm{~mm}$ in middle slope positions and $2.94 \mathrm{~mm}$ in lower slope positions $\left(F_{[2,17]}=10.79, p<0.001\right)$. Soils under shrubs had lower MMD than forest soil (paired-sample $t$ test $=2.96, n=18, p=0.04$ ). MMD did not differ among the three tested soil depths $\left(F_{[2,17]}=0.81\right.$, $p>0.05)$.

\section{Soil and ecosystem nutrient and carbon stocks}

Soil N concentrations were higher in shrubland than in forests (Table 1). Concentrations were also higher in upper and lower slope positions than in middle slope positions. $N$ concentration decreased with depth (Table 1). There was an enrichment of $\mathrm{N}$ relative to both $\mathrm{C}$ and $\mathrm{P}$ in shrubland lower-slope, and upper-slope soils, as reflected by the carbon and nitrogen (henceforth, $\mathrm{C} / \mathrm{N}$ ) and the nitrogen and phosphorus (henceforth, N/P) ratios (Table 1). There were no differences among land uses, slope positions, or soil depths in $\mathrm{P}$ concentration, although $\mathrm{C} / \mathrm{P}$ ratios decreased with soil depth (Table 1).

Soil C and N stocks decreased with higher slope position (Table 2). Both $\mathrm{C}$ and $\mathrm{N}$ diminished with soil depth, with the top $15 \mathrm{~cm}$ having substantially greater stocks. These dynamics did not differ substantially among land uses and slope positions (Fig. 3). Soil P stocks did not differ systematically by depth, but decreased with higher slope position in the forests (Table 2). In contrast, P stocks were greatest in the upper and lower slope positions in shrubland soils (Table 2). Soil C and P stocks were equal between land uses, but the $\mathrm{N}$ stock was greater in shrubland (Table 2).

Vegetation biomass differed greatly by land-use type, with forests having approximately 160 tonnes $\cdot$ ha $^{-1}$ (Supplementary Table $S 2^{1}$ ) and shrubland having less than 10 tonnes $\cdot \mathrm{ha}^{-1}$. Thus, $\mathrm{C}, \mathrm{N}$, and $\mathrm{P}$ stocks in biomass were respectively $58.46,0.56$, and 0.39 tonnes ha $^{-1}$ higher in forests than in shrubland (Table 2). Slope-position dynamics were consistent in forests, with stocks in lower slopes significantly greater than stocks in middle and upper slopes (Table 2). In shrubland, C stocks were highest in the middle slope position, and $\mathrm{N}$ stocks were lowest in the upper slope position, with no differences in P stocks (Table 2).

At the ecosystem level in the forests, all nutrients were greatest in the lower slope positions and lowest in the upper slope positions. At the shrubland ecosystem level, stocks of $\mathrm{C}$ and $\mathrm{N}$ were
Table 1. Bulk soil total $\mathrm{N}$ and $\mathrm{P}$ concentrations and $\mathrm{C} / \mathrm{N}, \mathrm{C} / \mathrm{P}$, and $\mathrm{N} / \mathrm{P}$ ratios are given for two land-use types in a hilly red soil land in subtropical China. $F$ values are given for the effects of land-use type (LUT), slope position (SP), and soil depth (SD) in a multi way analysis of variance.

\begin{tabular}{llllll}
\hline & Total & Total & Soil & Soil & Soil \\
& $\mathrm{N}\left(\mathrm{g} \cdot \mathrm{kg}^{-1}\right)$ & $\mathrm{P}\left(\mathrm{g} \cdot \mathrm{kg}^{-1}\right)$ & $\mathrm{C} / \mathrm{N}$ ratio & $\mathrm{C} / \mathrm{P}$ ratio & $\mathrm{N} / \mathrm{P}$ ratio \\
\hline $\begin{array}{l}\text { Land-use type } \\
\text { Shrubland }\end{array}$ & & & & & \\
Forests & $1.39 \pm 0.11$ & $0.21 \pm 0.01$ & $4.49 \pm 0.25$ & $35.58 \pm 4.87$ & $7.91 \pm 0.89$ \\
F values & & & & & \\
LUT & $12.52^{* * *}$ & $0.49 \mathrm{NS}$ & $12.76^{* * *}$ & $1.29 \mathrm{NS}$ & $6.02^{*}$ \\
SP & $8.20^{* * *}$ & $0.47 \mathrm{NS}$ & $4.07^{*}$ & $2.60 \mathrm{NS}$ & $3.53^{*}$ \\
SD & $94.57^{* * *}$ & $1.14 \mathrm{NS}$ & $9.54^{* * *}$ & $17.74^{* * *}$ & $6.03^{* *}$ \\
\hline
\end{tabular}

Note: Mean \pm 1 standard error. Significance levels: NS, not significant; ${ }^{*}, p<0.05$; ${ }^{* *}, p<0.01,{ }^{* * *}, p<0.001$.

greatest in the lower slope positions, whereas P stocks were greatest in the middle slope positions (Table 2).

\section{Organic $C$ stability in topsoil aggregates}

Mean organic $C$ concentrations in soil aggregates were not significantly different between forests and shrubland, but concentrations within specific aggregate size classes differed. In forests, organic $C$ concentration increased with decreasing size for aggregates $>0.25 \mathrm{~mm}$; the smallest aggregates had slightly lower organic $\mathrm{C}$ concentrations than the immediately larger aggregates (Fig. 4a). With shrubland, the highest organic $C$ concentration was found in aggregates $<0.25 \mathrm{~mm}$, whereas the lowest was in the $0.25-0.5 \mathrm{~mm}$ aggregates. Meanwhile, the $\mathrm{C} / \mathrm{N}$ and $\mathrm{C} / \mathrm{P}$ ratios in topsoil aggregates were mainly influenced by the land-use type (Figs. $4 b$ and $4 c$ ).

$\mathrm{CO}_{2}$ emissions from soil aggregates decreased during the course of the incubation. The first 24 days, accounting for one-third of the incubation length, generated $50 \%-65 \%$ of the total $\mathrm{CO}_{2}$ emitted during incubation. A greater percentage of total $\mathrm{CO}_{2}$ was emitted during this period in shrubland soils than in forest soils. For shrubland soils, total $\mathrm{CO}_{2}$ emissions were lower from aggregates $>1 \mathrm{~mm}$ than from smaller aggregates and were lower in the upper slope position than in the other slope positions (Fig. 5a). Forest soils similarly had increased emissions with decreasing aggregate size, with a drop off for aggregates $<0.25 \mathrm{~mm}$, and bulk soil emissions were higher in the upper and middle slope positions (Fig. 5b). Within aggregate size classes or bulk soil, forest soils consistently had lower $\mathrm{CO}_{2}$ emissions than shrubland soils.

\section{Discussion}

Ecosystem C, N, and P stocks were significantly increased in the forest plantation. Most of these increases appear to be driven by the massive difference in biomass between the two systems. The share of biomass $\mathrm{C}, \mathrm{N}$, and $\mathrm{P}$ was much greater in forests, so even though soil $\mathrm{N}$ and $\mathrm{P}$ stocks were lower than in shrubland, the total ecosystem-level stocks in forests were greater. Soil N concentrations were substantially lower in forests, and their biomass represented approximately one-third of the total $\mathrm{N}$ pool compared with only $13 \%$ in shrubland. The combination of reduced soil $\mathrm{N}$ and increased biomass $\mathrm{N}$ in the forest seems to suggest that $\mathrm{N}$ inputs into the system such as $\mathrm{N}$ fixation and atmospheric deposition were insufficient to offset the vegetation's $\mathrm{N}$ uptake (Yang et al. 2014). Therefore, sustained biomass removal from the forest system could deplete $\mathrm{N}$ ecosystem stocks over time.

Although P content did not differ with slope position in shrubland, there was a substantial difference between the upper and lower slope positions in the forest. This seems to suggest that forested hilltops are more likely to lose $\mathrm{P}$, whereas forested lower slopes are better able to retain it, perhaps due to the greater amount of litter and understory vegetation (Fu et al. 2004). Although plant 
Table 2. C, N, and P stocks (tonnes $\cdot \mathrm{ha}^{-1}$ ) in secondary shrublands and forest plantations in a hilly red soil land of subtropical China.

\begin{tabular}{|c|c|c|c|c|}
\hline Modules & $\begin{array}{l}\text { Slope } \\
\text { position }\end{array}$ & Shrublands & Forests & $\begin{array}{l}\text { Significance } \\
\text { level }\end{array}$ \\
\hline \multicolumn{5}{|l|}{ C stocks } \\
\hline \multirow[t]{4}{*}{ Soils } & Upper & $45.75 \pm 1.43 b$ & $38.11 \pm 3.23 \mathrm{C}$ & $p<0.05$ \\
\hline & Middle & $43.99 \pm 2.80 \mathrm{~b}$ & $44.48 \pm 5.91 \mathrm{~B}$ & $p>0.05$ \\
\hline & Lower & $52.90 \pm 4.37 \mathrm{a}$ & $52.68 \pm 3.00 \mathrm{~A}$ & $p>0.05$ \\
\hline & Mean & $47.55 \pm 2.21$ & $45.09 \pm 3.28$ & $p>0.05$ \\
\hline \multirow[t]{4}{*}{ Plants } & Upper & $4.35 \pm 1.11 b$ & $56.19 \pm 5.01 \mathrm{~B}$ & $p<0.001$ \\
\hline & Middle & $7.08 \pm 4.08 \mathrm{a}$ & $59.87 \pm 1.34 \mathrm{~B}$ & $p<0.001$ \\
\hline & Lower & $4.51 \pm 0.80 \mathrm{~b}$ & $82.62 \pm 5.47 \mathrm{~A}$ & $p<0.001$ \\
\hline & Mean & $5.31 \pm 1.24$ & $66.22 \pm 5.58$ & $p<0.001$ \\
\hline \multirow[t]{4}{*}{ Ecosystem level } & Upper & $50.10 \pm 0.33 b$ & $94.30 \pm 8.23 \mathrm{C}$ & $p<0.001$ \\
\hline & Middle & $51.06 \pm 1.29 b$ & $104.34 \pm 4.58 \mathrm{~B}$ & $p<0.001$ \\
\hline & Lower & $57.40 \pm 5.16 a$ & $135.29 \pm 2.45 \mathrm{~A}$ & $p<0.001$ \\
\hline & Mean & $52.85 \pm 2.00$ & $111.31 \pm 8.20$ & $p<0.001$ \\
\hline \multicolumn{5}{|l|}{ N stocks } \\
\hline \multirow{4}{*}{ Soils } & Upper & $9.38 \pm 0.19 b$ & $7.17 \pm 0.67 \mathrm{C}$ & $p<0.001$ \\
\hline & Middle & $8.63 \pm 1.54 \mathrm{~b}$ & $7.99 \pm 0.11 \mathrm{~B}$ & $p<0.001$ \\
\hline & Lower & $12.30 \pm 1.87 \mathrm{a}$ & $9.81 \pm 0.93 \mathrm{~A}$ & $p<0.001$ \\
\hline & Mean & $10.10 \pm 0.95$ & $8.32 \pm 0.57$ & $p<0.001$ \\
\hline \multirow[t]{4}{*}{ Plants } & Upper & $1.32 \pm 0.04 \mathrm{~b}$ & $3.51 \pm 0.36 \mathrm{~B}$ & $p<0.001$ \\
\hline & Middle & $1.61 \pm 0.03 a$ & $3.57 \pm 0.15 \mathrm{~B}$ & $p<0.001$ \\
\hline & Lower & $1.51 \pm 0.02 \mathrm{a}$ & $4.38 \pm 0.21 \mathrm{~A}$ & $p<0.001$ \\
\hline & Mean & $1.48 \pm 0.06$ & $3.82 \pm 0.21$ & $p<0.001$ \\
\hline \multirow[t]{4}{*}{ Ecosystem level } & Upper & $10.70 \pm 0.15 b$ & $10.68 \pm 1.03 \mathrm{C}$ & $p>0.05$ \\
\hline & Middle & $10.23 \pm 1.56 b$ & $11.56 \pm 0.05 B$ & $p<0.01$ \\
\hline & Lower & $13.81 \pm 1.85 a$ & $14.19 \pm 0.71 \mathrm{~A}$ & $p<0.01$ \\
\hline & Mean & $11.58 \pm 0.95$ & $12.14 \pm 0.74$ & $p<0.01$ \\
\hline \multicolumn{5}{|l|}{ P stocks } \\
\hline \multirow[t]{4}{*}{ Soils } & Upper & $1.30 \pm 0.19 b$ & $1.08 \pm 0.10 \mathrm{~B}$ & $p<0.001$ \\
\hline & Middle & $1.68 \pm 0.24 \mathrm{a}$ & $1.54 \pm 0.38 \mathrm{AB}$ & $p<0.01$ \\
\hline & Lower & $1.33 \pm 0.37 b$ & $2.22 \pm 1.10 \mathrm{~A}$ & $p<0.001$ \\
\hline & Mean & $1.43 \pm 0.15$ & $1.61 \pm 0.37$ & $p>0.05$ \\
\hline \multirow[t]{4}{*}{ Plants } & Upper & $0.07 \pm 0.00 \mathrm{a}$ & $0.25 \pm 0.03 \mathrm{~B}$ & $p<0.001$ \\
\hline & Middle & $0.09 \pm 0.01 \mathrm{a}$ & $0.27 \pm 0.01 \mathrm{~B}$ & $p<0.001$ \\
\hline & Lower & $0.08 \pm 0.00 \mathrm{a}$ & $0.36 \pm 0.03 \mathrm{~A}$ & $p<0.001$ \\
\hline & Mean & $0.08 \pm 0.01$ & $0.29 \pm 0.02$ & $p<0.001$ \\
\hline \multirow[t]{4}{*}{ Ecosystem level } & Upper & $1.36 \pm 0.19 b$ & $1.33 \pm 0.13 \mathrm{C}$ & $p>0.05$ \\
\hline & Middle & $1.76 \pm 0.26 \mathrm{a}$ & $1.80 \pm 0.37 \mathrm{~B}$ & $p>0.05$ \\
\hline & Lower & $1.41 \pm 0.37 b$ & $2.57 \pm 1.07 \mathrm{~A}$ & $p<0.001$ \\
\hline & Mean & $1.51 \pm 0.15$ & $1.90 \pm 0.37$ & $p<0.05$ \\
\hline
\end{tabular}

Note: Mean \pm 1 standard error. $p$ values based on paired-sample $t$ tests. Different lowercase and capital letters indicate significant difference among different slope positions within secondary shrublands and forest plantations, respectively, at the $p<0.05$ level.

stocks of P were higher in the forest than the shrubland, soil P stocks dwarfed plant $\mathrm{P}$ content, indicating that $\mathrm{P}$ loss may not limit plant productivity in the short term.

We also saw considerable variability in soil and vegetation properties among the different slope positions. Under both land covers, the upper slope position had higher bulk density, smaller distribution of soil aggregates, and higher percentage of stone mass. The effect of slope position on the distribution of nutrients and physical soil characteristics is likely due to erosion, with runoff and sediment from the upper slope position accumulating in the lower slope position (Luizâo et al. 2004; Tang et al. 2010). In our study, upper slope soil stocks of $\mathrm{C}, \mathrm{N}$, and $\mathrm{P}$ were all lower in the forest than in the shrubland, suggesting that forests might be more prone to nutrient loss from the tops of hills.

There is some concern about the risk of soil organic C loss resulting from human activity during forest establishment (Karu et al. 2009). Forests generate much higher organic inputs to the soil through root and foliar litters; therefore, the lack of difference in soil organic matter between the two land uses may indicate an initial loss of soil $\mathrm{C}$ that has gradually been corrected over the past 19 years. Although Tang et al. (2010) found much higher fractions of macroaggregates at a restored forest site compared with a degraded forest site, we found no significant difference in the composition of topsoil aggregates in our study. Thus, slope position exerted a greater effect on topsoil aggregate distribution than land use. Organic $C$ concentrations in topsoil aggregates were also not different between the two land-use types. However, the cumulative $\mathrm{CO}_{2}$ emission of each aggregate was generally lower in forests than in shrubland. The relative size of $C$ pools accessible during the incubation decreased with the process of reforestation on shrubland. This may be due to different chemical qualities in soil organic $C$ inputs (Six et al. 2002). We found that the $\mathrm{C} / \mathrm{N}$ and $\mathrm{C} / \mathrm{P}$ ratios in soil aggregates were generally higher in forests than in shrubland. Given the comparable soil $\mathrm{C}$ contents for both land uses and the reduced stability of the shrubland soil $C$ pool, we hypothesize that $C$ inputs to soil are greater under shrubs, potentially producing a more active microbial community (Liu et al. 2012). An active microbial community can be a mixed blessing as it can lead to a tighter nutrient cycling and an increased competition for nutrients (Cotrufo et al. 1995), potentially explaining the lower $\mathrm{C} / \mathrm{N}$ and $\mathrm{C} / \mathrm{P}$ ratios found in soils under shrubs. Overall, reforestation effects on soil nutrient dynamics 
Fig. 3. Bulk soil (a) organic C, (b) N, and (c) P stocks by land-use type, slope position, and soil depth in a hilly red soil land of subtropical China. Error bars represent \pm 1 standard error. Different lowercase letters indicate significantly different values at various depths among land use type slope positions at the $p<0.05$ level. Note the differences in scale.
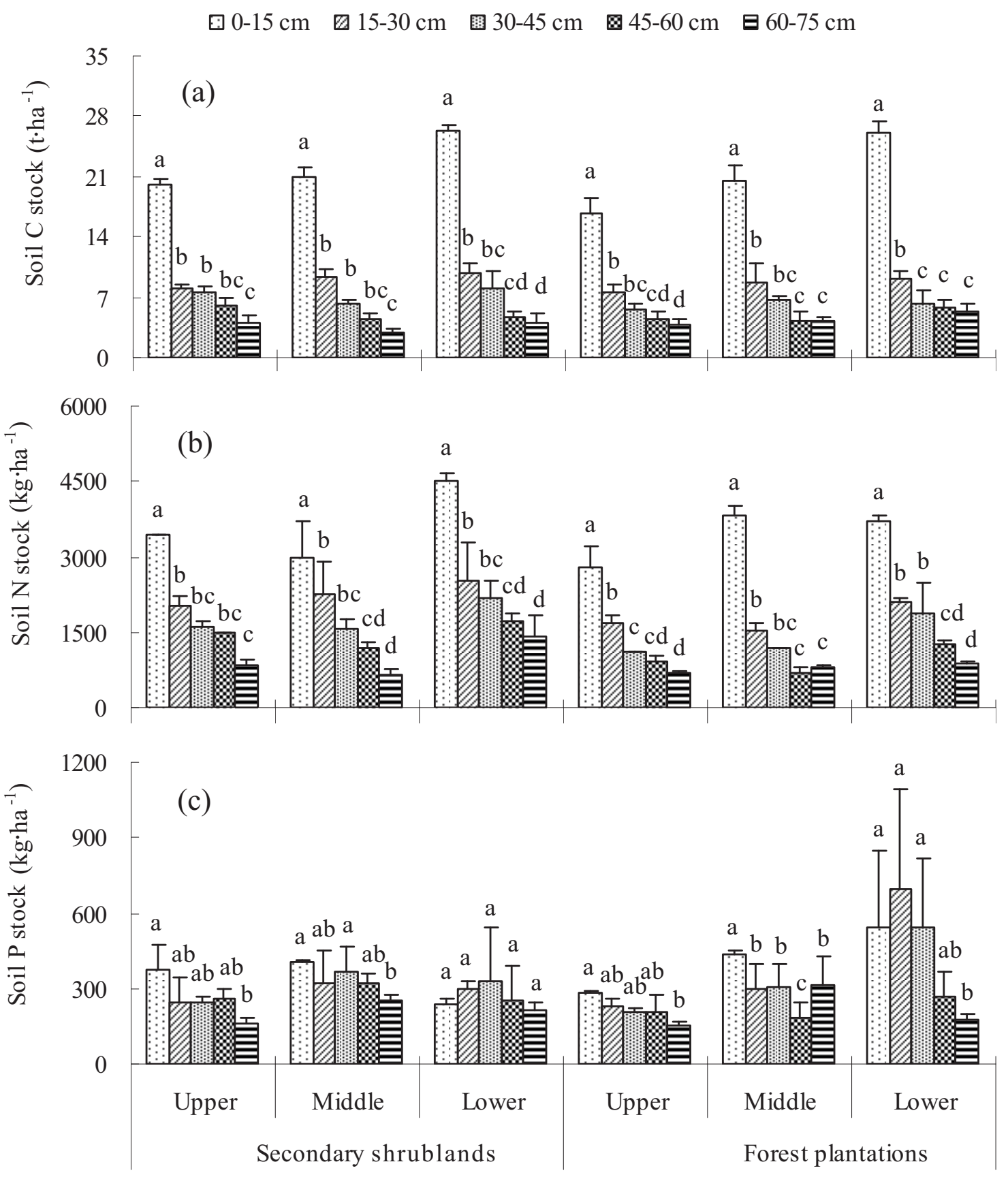

was closely associated with C cycling (Yang et al. 2011) and may reflect characteristics of the nutrient element.

The stability of soil organic $C$ could be caused by enhanced soil aggregation, which provides microenvironments for constructing physical protection and absorbing particle organic matter (Six et al. 2000). In both land covers, the total amount of $\mathrm{CO}_{2}$ emission was much lower in the larger aggregates than in the smaller aggregates, silt, and clay soil, but their organic C concentrations varied minimally among various aggregate size classes. Consequently, topsoil organic $C$ at lower slope positions, especially in forest plantations, was more stable than at upper positions due to the increase in the relative mass of $>5 \mathrm{~mm}$ aggregates and decreased mass of $<0.25 \mathrm{~mm}$ aggregates. Soil aggregation and or- ganic C stability were significantly improved in 19-year-old forest plantations, compared with secondary shrubland. The main factor driving this lower soil organic-mineralization potential was not aggregate formation but might be the decrease in soil $\mathrm{N}$ concentrations and in $\mathrm{N}$ limitation with the higher $\mathrm{C} / \mathrm{N}$ and lower $\mathrm{N} / \mathrm{P}$ ratios in early forest plantations (Gong et al. 2013).

Finally, we should caution the reader that this work was conducted on a single slope and is best considered as a case study. We have endeavored to identify general patterns that could condition expectations for the behavior of this type of system, but these patterns may be sensitive to ecological and historical contexts. Thus, extreme caution should be taken when drawing broader inferences from our findings. 
Fig. 4. (a) Topsoil $(0-15 \mathrm{~cm})$ organic $C$ concentration and the ratios of $(b) \mathrm{C} / \mathrm{N}$ and $(c) \mathrm{C} / \mathrm{P}$ by land-use type, slope position, and soil aggregate size class in a hilly red soil land of subtropical China. Error bars represent \pm 1 standard error. Significance levels: NS, not significant; ${ }^{*}, p<0.05$; ${ }^{* *}, p<0.01$; ***, $p<0.001$. Note the differences in scale.

$\square>5 \mathrm{~mm}$ 圈 2-5 mm $\square 1-2 \mathrm{~mm} \mathbf{\Delta} 0.5-1 \mathrm{~mm} \square 0.25-0.5 \mathrm{~mm}$ 田 $<0.25 \mathrm{~mm}$
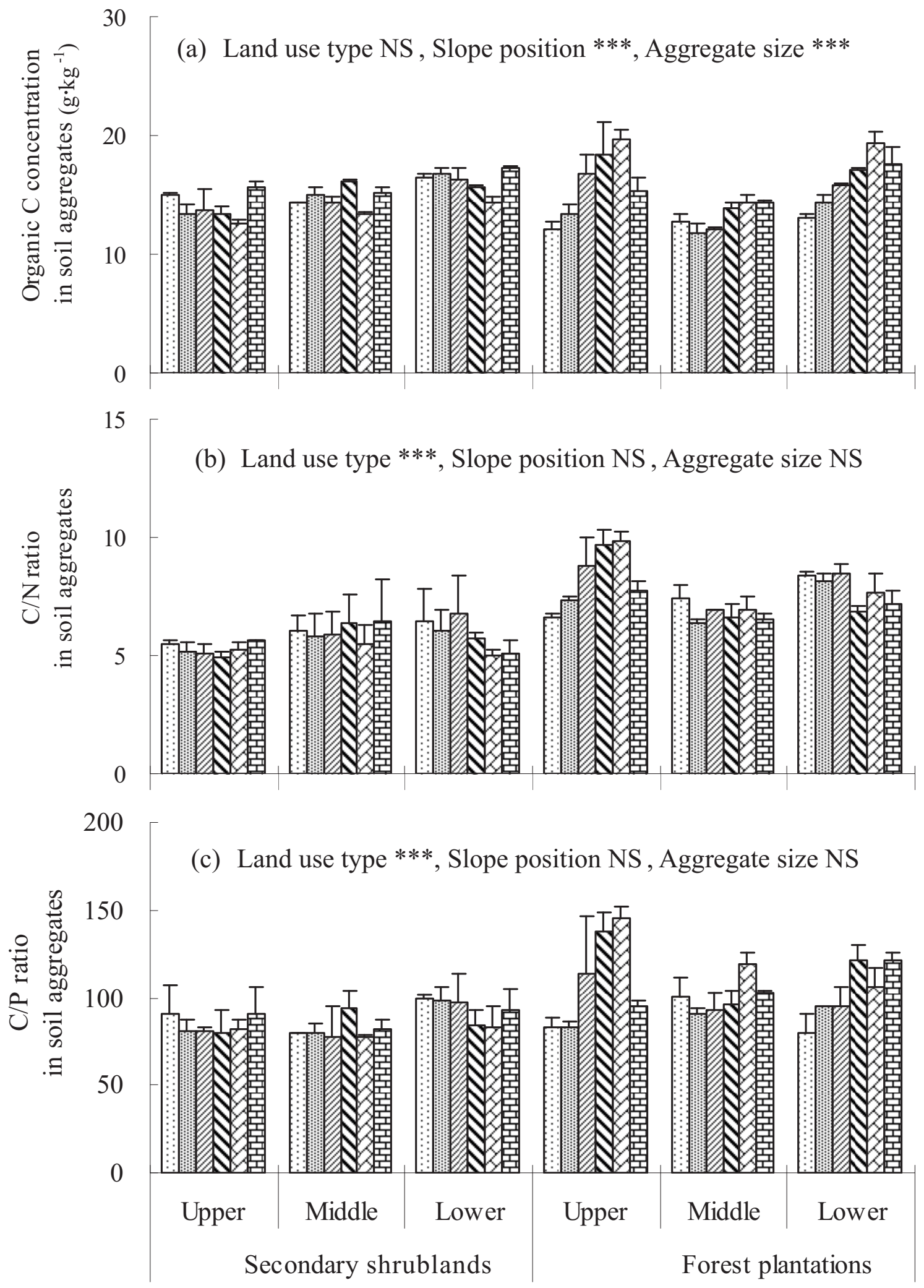
Fig. 5. Topsoil cumulative $\mathrm{CO}_{2}$ emission $\left(\mathrm{mg} \mathrm{CO}_{2} \cdot(\mathrm{kg} \text { dry soil) })^{-1}\right)$ during laboratory incubation (in days (d)) in (a) secondary shrubland and (b) forest plantations by slope position and soil aggregate size class in a hilly red soil land of subtropical China. Significance levels: NS, not significant; ${ }^{*}, p<0.05 ;{ }^{* *}, p<0.001$. Lowercase letters indicate significantly different cumulative $\mathrm{CO}_{2}$ emissions among aggregate size classes within a slope position, and capital letters indicate significant differences among the three slope positions for bulk soil at the $p<0.05$ level.
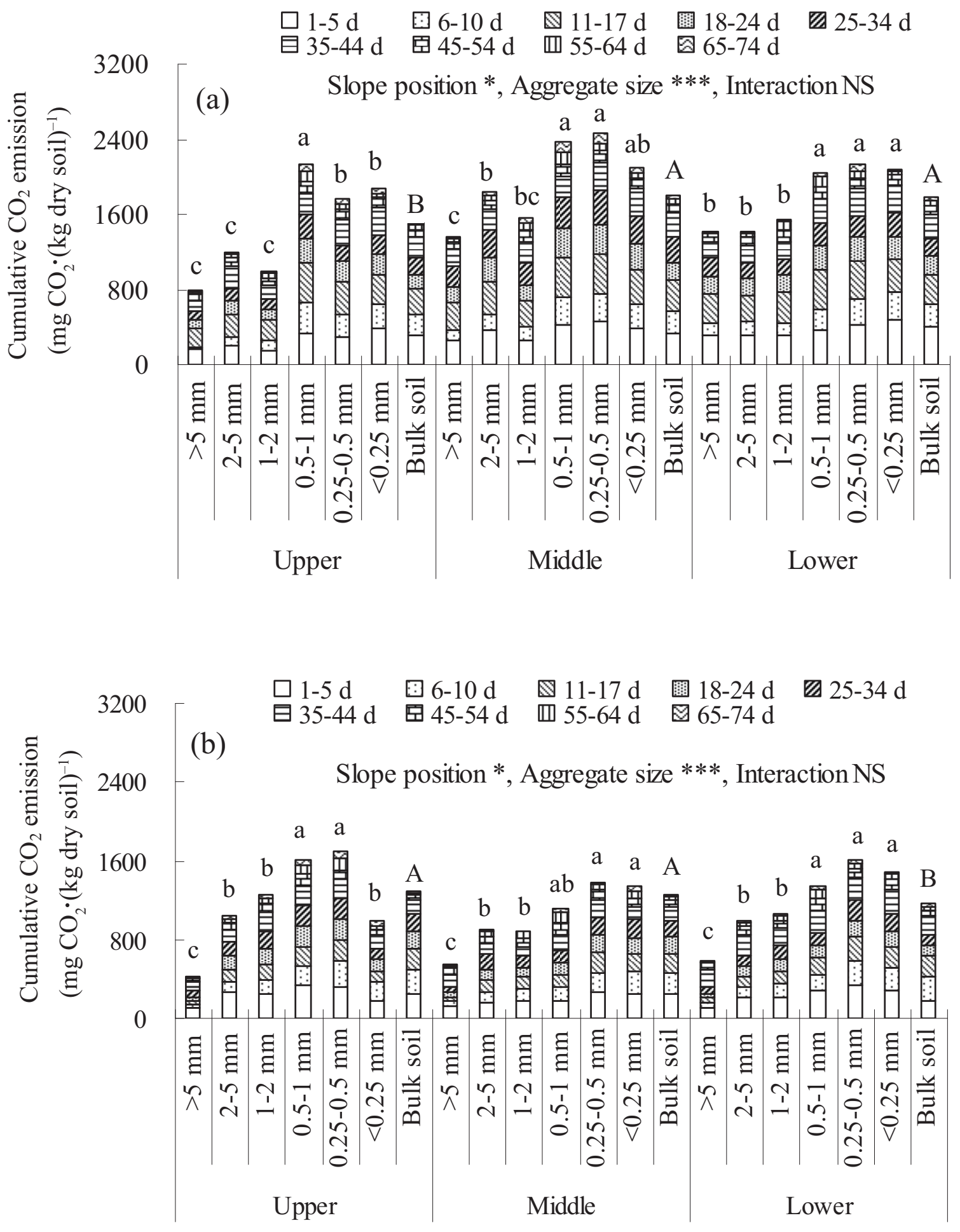

\section{Conclusions}

Forested land was generally more sensitive to slope position than shrubland, but there is no indication that shrubs actually provided more desirable ecosystem effects. The forest tended to have larger nutrient pools than the shrubland, although with smaller pools in the soil and larger pools in plants. Soil aggregates were qualitatively different between forests and shrubland. Aggregates of specific sizes were enriched in organic $C$ in the two systems. Forest aggregates generally emitted less $\mathrm{CO}_{2}$ during incubation but had similar $\mathrm{C}$ concentrations. Thus, soil aggregates in the forest had more stable $C$ than in the shrubland. Finally, slope position influenced restoration effectiveness in the red soil hilly region. 


\section{Acknowledgements}

This study was supported by grants from National Basic Research Program of China (973 Program, No. 2012CB416903), the National Natural Science Foundation of China (Nos. 31160107 and 31360179), and the Jiangxi Provincial Department of Science and Technology (Nos. 20122BCB23005 and 2012BAB204005). The comments from two anonymous reviewers and the Associate Editor have greatly improved the quality of this paper.

\section{References}

Allen, S.E. 1989. Chemical analysis of ecological materials. Blackwell Scientific Publications, Oxford, UK

Berthrong, S.T., Jobbagy, E.G., and Jackson, R.B. 2009. A global meta-analysis of soil exchangeable cations, $\mathrm{pH}$, carbon, and nitrogen with afforestation. Ecol. Appl. 19(8): 2228-2241. doi:10.1890/08-1730.1.

Brown, S., and Lugo, A.E. 1990. Effects of forest clearing and succession on the carbon and nitrogen content of soils in Puerto Rico and US Virgin Islands. Plant Soil, 124(1): 53-64. doi:10.1007/BF00010931.

Chen, F.-S., Zhang, Y.-M., Hu, X.-F., Feng, X., Ren, W., and Liu, Y.-Q. 2012. The pattern of ecosystem carbon stock in steep slope wild shrubs and neighboring forest plantations in hilly red soil area. J. Soil Water Conserv. 26(1): 151-155. [In Chinese.]

Cotrufo, M.F., Ineson, P., and Roberts, J.D. 1995. Decomposition of birch leaf litters with varying C-to-N ratios. Soil Biol. Biochem. 27: 1219-1221. doi:10. 1016/0038-0717(95)00043-E.

Fang, J.Y., Chen, A.P., Peng, C.H., Zhao, S.Q., and Ci, L. 2001. Changes in forest biomass carbon storage in China between 1949 and 1998. Science, 292(5525): 2320-2322. doi:10.1126/science.1058629.

- Fu, B.J., Liu, S.L., Chen, L.D., Lu, Y.H., and Qiu, J. 2004. Soil quality regime in relation to land cover and slope position across a highly modified slope landscape. Ecol. Res. 19(1): 111-118. doi:10.1111/j.1440-1703.2003.00614.X.

Gong, X., Liu, Y., Li, Q., Wei, X., Guo, X., Niu, D., Zhang, W., Zhang, J., and Zhang, L. 2013. Subtropic degraded red soil restoration: is soil organic carbon buildup limited by nutrients supply. For. Ecol. Manage. 300: 77-87. doi:10. 1016/j.foreco.2012.12.002.

Hooker, T.D., and Compton, J.E. 2003. Forest ecosystem carbon and nitrogen accumulation during the first century after agricultural abandonment. Ecol. Appl. 13(2): 299-313. doi:10.1890/1051-0761(2003)013[0299:FECANA]2.0.CO;2.

Huang, L., Liu, J., Shao, Q., and Xu, X. 2012. Carbon sequestration by forestation across China: past, present, and future. Renewable Sustainable Energy Rev. 16(2): 1291-1299. doi:10.1016/j.rser.2011.10.004.

Karu, H., Szava-Kovats, R., Pensa, M., and Kull, O. 2009. Carbon sequestration in a chronosequence of Scots pine stands in a reclaimed opencast oil shale mine. Can. J. For. Res. 39(8): 1507-1517. doi:10.1139/X09-069.

Kemper, W.D., and Rosenau, R.C. 1986. Aggregate stability and size distribution. In Methods of soil analysis, Part 1. 2nd edition. Edited by A. Klute. American Society of Agronomy and Soil Science Society of America, Madison, Wisconsin, USA. Agronomy Monograph 9. pp. 425-442.
Lal, R. 2005. Forest soils and carbon sequestration. For. Ecol. Manage. 220(1-3): 242-258. doi:10.1016/j.foreco.2005.08.015.

Li, D., Niu, S., and Luo, Y. 2012. Global patterns of the dynamics of soil carbon and nitrogen stocks following afforestation: a meta-analysis. New Phytol. 195(1): 172-181. doi:10.1111/j.1469-8137.2012.04150.x.

Li, W.H. 2004. Degradation and restoration of forest ecosystems in China. For. Ecol. Manage. 201(1): 33-41. doi:10.1016/j.foreco.2004.06.010.

Liu, Y.-Q., and Guo, X.-M. 1997. Probe on patterns of afforestation for barren hill with soil and water conservation on low hills in Jiangxi. Res. Soil Water Conserv. 4(2): 166-170. [In Chinese.]

Liu, Y., Wei, X., Guo, X., Niu, D., Zhang, J., Gong, X., and Jiang, Y. 2012. The long-term effects of reforestation on soil microbial biomass carbon in subtropic severe red soil degradation areas. For. Ecol. Manage. 285(1): 77-84. doi:10.1016/j.foreco.2012.08.019.

Luizâo, R.C.C., Luizâo, F.J., Paiva, R.Q., Monteiro, T.F., Sousa, L.S., and Kruijt, B. 2004. Variation of carbon and nitrogen cycling processes along a topographic gradient in a central Amazonian forest. Glob. Chang. Biol. 10(5): 592-600. doi:10.1111/j.1529-8817.2003.00757.x.

Sainju, U.M. 2006. Carbon and nitrogen pools in soil aggregates separated by dry and wet sieving methods. Soil Sci. 171(12): 937-949. doi:10.1097/01.ss0000228062. 30958.5a.

Six, J., Elliott, E.T., and Paustian, K. 2000. Soil macroaggregate turnover and microaggregate formation: a mechanism for $\mathrm{C}$ sequestration under no-tillage agriculture. Soil Biol. Biochem. 32(14): 2099-2103. doi:10.1016/S0038-0717(00) 00179-6.

-Six, J., Callewaert, P., Lenders, S., De Gryze, S., Morris, S.J., Gregorich, E.G., Paul, E.A., and Paustian, K. 2002. Measuring and understanding carbon storage in afforested soils by physical fractionation. Soil Sci. Soc. Am. J. 66(6): 1981-1987. doi:10.2136/sssaj2002.1981.

SPSS Inc. 2007. SPSS for Windows. Version 16.0. SPSS Inc., Chicago, Illinois, USA.

Tang, X., Liu, S., Liu, J., and Zhou, G. 2010. Effects of vegetation restoration and slope positions on soil aggregation and soil carbon accumulation on heavily eroded tropical land of southern China. J. Soils Sediments, 10(3): 505-513. doi:10.1007/s11368-009-0122-9.

Wei, X.R., Shao, M.G., Fu, X.L., and Horton, R. 2010. Changes in soil organic carbon and total nitrogen after 28 years grassland afforestation: effects of tree species, slope position, and soil order. Plant Soil, 331(1-2): 165-179. doi: 10.1007/s11104-009-0243-3.

Wei, X., Li, Q., Liu, Y., Liu, S., Guo, X., Zhang, L., Niu, D., and Zhang, W. 2013. Restoring ecosystem carbon sequestration through afforestation: a subtropic restoration case study. For. Ecol. Manage. 300(1): 60-67. doi:10.1016/j.foreco. 2012.06.018

Yang, K., Zhu, J., and Xu, S. 2014. Influences of various forms of nitrogen additions on carbon mineralization in natural secondary forests and adjacent larch plantations in northeast China. Can. J. For. Res. 44(5): 441-448. doi:10. 1139/cjfr-2013-0485.

-Yang, Y., Luo, Y., and Finzi, A.C. 2011. Carbon and nitrogen dynamics during forest stand development: a global synthesis. New Phytol. 190(4): 977-989. doi:10.1111/j.1469-8137.2011.03645.x.

Zhao, Q.-G. 2002. The red soil material cycling and its regulation. Science Press, Beijing. [In Chinese.] 
This article has been cited by:

1. Xiang-Min Fang, Lynn M. Christenson, Fang-Chao Wang, Ju-Ping Zeng, Fu-Sheng Chen. 2016. Pine caterpillar outbreak and stand density impacts on nitrogen and phosphorus dynamics and their stoichiometry in Masson pine (Pinus massoniana) plantations in subtropical China. Canadian Journal of Forest Research 46:5, 601-609. [Abstract] [Full Text] [PDF] [PDF Plus] [Supplemental Material] 